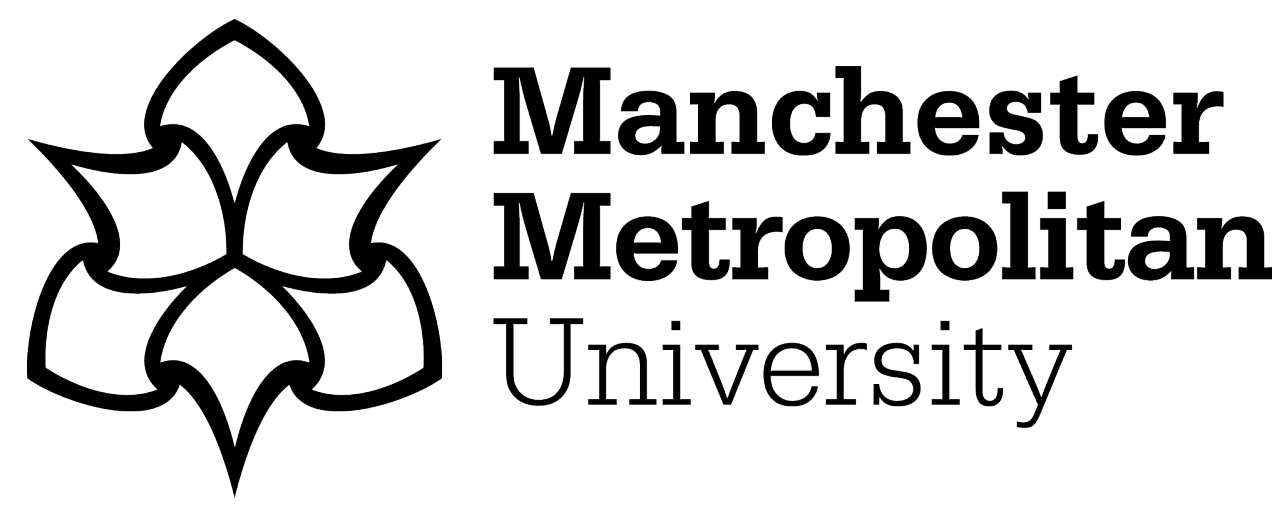

Antoniadou, M (2017) The House system: evaluating its role in the experience of business students. Innovations in Education and Teaching International, 54 (4). pp. 313-324. ISSN 1470-3297

Downloaded from: https://e-space.mmu.ac.uk/617174/

Version: Accepted Version

Publisher: Taylor \& Francis (Routledge)

DOI: https://doi.org/10.1080/14703297.2016.1146622

Please cite the published version 


\title{
The House system: Evaluating its role in the experience of business students
}

\author{
Marilena Antoniadou
}

To cite this article: Marilena Antoniadou (2016): The House system:

Evaluating its role in the experience of business students, Innovations in Education and Teaching International, DOI:

$\underline{10.1080 / 14703297.2016 .1146622}$

\section{The House system: Evaluating its role in the experience of business students}

Marilena Antoniadou

Faculty of Business \& Iaw, department of Management, Manchester Metropolitan university, Manchester, uK

\begin{abstract}
This paper presents a case study of students' experiences of the House system, an innovative scheme introduced for business students, aiming to enhance student experience. The findings are based on a survey of 350 students and 4 group interviews. Analysis of the findings, both statistical and qualitative, indicated perceived clear benefits for the House system, including making friendships, being mentored by supportive staff and skills development. However, they also perceived disadvantages, particularly with regard to unawareness of the system, and limited extra-curriculum and employability activities. The paper concludes that active participation in the House system has a potentially useful role in creating a meaningful and collaborative environment amongst students and staff.
\end{abstract}

\section{KEYWORDS}

student experience; social support; highereducation; house system 


\section{Introduction}

Universities are increasingly seen as a component in a consumer society, and degrees as products to be consumed (Constanti \& Gibbs, 2004; Ritzer, 1999). In the light of a move to mass higher education $(\mathrm{HE})$, a consequential need to enhance the support that undergraduate students receive in their overall experience is essential (Buultjens \& Robinson, 2011; King, Morison, Reed, \& Stachow, 1999; Oldfield \& Baron, 2000).

Student experience appears as a wide-ranging term in the literature, which makes it difficult to define it assimplyone thing. It islargelyagreed that the academic aspects of teaching, learning and assessment, together with the perceived emotional and developmental aspects of student life are parts of it (Benckendorff, Ruhanen, \& Scott, 2009; Christie, Tett, Cree, Hounsell, \& McCune, 2008; Palmer, O'Kane, \& Owens, 2009). The 1994 Group of Universities (2007) suggested that key areas of the student experience are namely teaching, support and facilities and employability which are developed both inside the academic curriculum and through engagement in extra-curricular activities. In seeking to develop an inventory of the determinants influencing student experience based on themes from the literature, Jones (2010) outlined seven priority areas:

(1) Student expectations

Communicating with students effectively about university and student life, from first contact through to becoming alumni, is essential in assisting them with settling in and meeting their expectations. Good service provision and the devotion of attention to students ascertain their expectations, without adopting a marketing approach, in which the customer is always right (Scott, 1999).

CONTACT Marilena antoniadou m.antoniadou@mmu.ac.uk

(2) Transition

The development of networks from pre-entry to joining the course and beyond has more far-reaching implications than merely that of making friends (Kantanis, 2000). Creating a sense of belonging on campus, as a feeling of fit in and inclusion within the wider educational environment is vital for all periods of the student journey (Hockings, Cooke, \& Bowl, 2007; Ramsden, 2008).

(3) Peers

Socialisation with more experienced peers can serve as a source of support, which enhances newcomers'sense of belonging and involvement (Allen, McManus, \& Russell, 1999). Peer networks contribute to enhanced academic achievement and self-motivation, as well as to greater enjoyment of university life (Menzies \& Baron, 2014; Peat, dalziel, \& Grant, 2001).

(4) Other Stakeholders

The influence of family, culture and the media is important in influencing students' perceptions about careers, which shows significant potential application to the university commitment in careers counselling and to the employability skills curriculum. Aspirations of employability can be a product of societal expectations, which establishes that students with a higher level of social capital expect better employment after graduation (Rothwell, Herbert, \& Rothwell, 2008).

(5) The Programme

Embedded in this category is the role of academics, as the facilitators of learning and teaching (Thomas, 2002). Students present higher levels of engagement and learning when academics use active and collaborative learning techniques, interact with students, support them in personal and academic issues, and challenge them academically (Umbach \& Wawrzynski, 2005).

(6) Extracurricular activity

Out-of-class events act as a mechanism for students'learning and development (Kuh, 1995). They also result to beneficial outcomes, such as critical thinking, relational and organisational skills, with implications on their academic, social and intellectual performance (Terenzini, Pascarella, \& Blimling, 1996).

(7) Employability 
In the light of the introduction of tuition fees in England, predictions show a shift in student choice towards employability-focused programmes (Foskett, Roberts, \& Maringe, 2006). Universities, then, have a major role in influencing students' impressions about their careers by seeking to provide them with a realistic portrayal of their type of profession (Byrne \& Willis, 2005).

\section{The House system}

Based on the need to enhance the students experience and to provide a sense of belonging to its students, the Manchester Metropolitan University introduced the House system in 2012 within its biggest programme, Business Management. The rationale for this social-support system derived from the programme's considerable and continuously growing size. The increasingly competitive market amongst institutions has generated issues of student experience, satisfaction and retention (King et al., 1999; Oldfield \& Baron, 2000), which the Manchester Metropolitan University aimed to address, as one of the Universities that has seen a rapid growth in its student numbers, becoming one of the UK's most popular university - based on its UCAS applications. In the context of rapid expansion, five Manchester-themed Houses, Acresfield, Addy, Castlefield, Petersfield and Turing act as social groups within the Business degree aimed at placing their students at the social epicentre of university life and creating the conditions for enhancing their sense-of-belonging within the programme (Figure 1). Students enjoy themed-identification symbols, social and academic activities, whilst the House tutors are committed to ensure that the programme provides the broadest possible range of in-class and out-of-class services to their designated cohort of students (Table 1). 


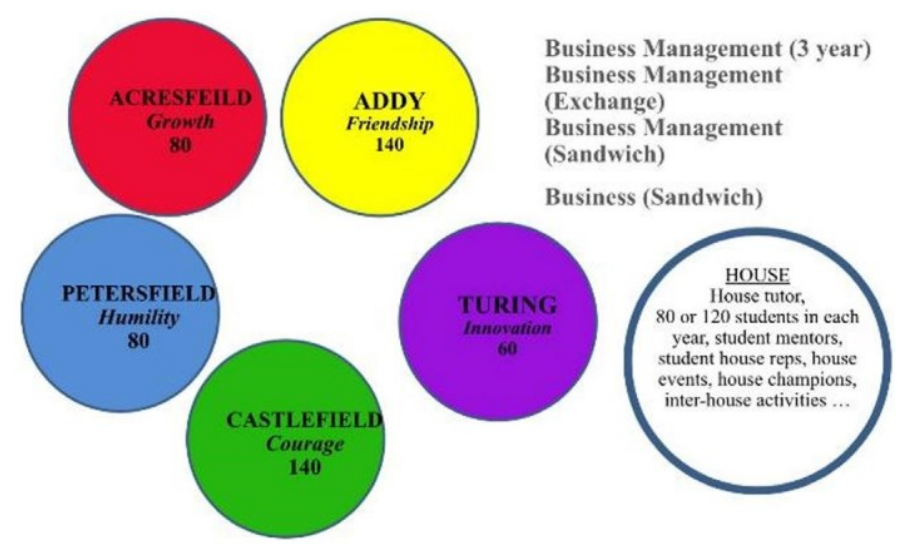

Figure 1. the house system.

Table 1. house/house tutors' aims.

\begin{tabular}{|c|c|}
\hline Student experience area & House tutor responsibilities \\
\hline studentexpectations & $\begin{array}{l}\text { day-to-day responsibility for the management of a student cohort } \\
\text { Provides information on rights, treatment, obligations, regulations and procedures } \\
\text { Ensuresthatstudenttimetables areclearly communicated to students. } \\
\text { Each house differs in colours and themes to give a sense of identity/belonging }\end{array}$ \\
\hline transition & $\begin{array}{l}\text { leads induction } \\
\text { organises workshops to develop friendships and team bonding } \\
\text { Personal tutorsupport }\end{array}$ \\
\hline the programme & $\begin{array}{l}\text { Ensures the programme runs smoothly and handles problems and conflicts } \\
\text { Works with the coordinatoron the further development of the programme } \\
\text { conveys news, changes and other information about the programme } \\
\text { Maintains frequent communication with students, including feedback on actions taken } \\
\text { Monitors student progress }\end{array}$ \\
\hline otherstakeholders & $\begin{array}{l}\text { organises visit lectures inviting parents and the media } \\
\text { allows opportunities for parents/media to meet the Programme team }\end{array}$ \\
\hline Peers & $\begin{array}{l}\text { recruits/liaises with student representatives } \\
\text { allows contacts with alumniorganises house events to allow meetings with students from } \\
\text { other Years }\end{array}$ \\
\hline Extracurricular activities & organises events and business competitions outside teaching hours \\
\hline $\begin{array}{l}\text { Employability and skills } \\
\text { development }\end{array}$ & $\begin{array}{l}\text { Each house has an alumnus, who visits and mentors the students } \\
\text { creates opportunities for students to develop their employability/academic skills }\end{array}$ \\
\hline
\end{tabular}

Two years after the system's launch, there was no attempt to assess its impact on the student experience. Toaddress this, the current study aimed to evaluate the House system in relation to student experience, from the students'perspective. The specific objectives were: (i) to explore students'levels of awareness of the House system, (ii) to explore students'views in relation to student experience aspects and (iii) to identify benefits and limitations within the House system.

\section{Phase 1}

A web questionnaire, utilising Qualtrics, was designed and circulated via email with a hyperlink to the actual questionnaire. The target population, defined as the total group of people from whom the researcher can obtain information that would meet the research objectives (Cohen, Manion, \& Morrison, 2007), comprised all the first and second-yearstudents registered in the Business Management Programme $(N=775)$. Firstand second-yearstudentswereexclusivelychosenfor thestudy, because they have had the opportunity to engage with the House system since the verystart of their studies (2012 onwards), whilst in the finalyear thesystem wasnotapplied. Thequestionnaireconsisted of 14questions 
Table2. respondents demographicmix.

\begin{tabular}{llc}
\hline Year of study & First Year & $58.7 \%$ \\
gender & second Year & $41.3 \%$ \\
& Male & $49.3 \%$ \\
nationality & Female & $50.7 \%$ \\
& uK & $82.7 \%$ \\
\multirow{2}{*}{ Mode of studies } & Eu (non-uKo & $14.7 \%$ \\
& International (non-Eu) & $2.7 \%$ \\
& Full-time & $60 \%$ \\
\hline
\end{tabular}

${ }^{a}$ students whose programme of study includes a year in industry.

including multiple choice, matrix and close-ended. The questions were influenced by the dimensions of thestudent experience as identified in the literature (e.g. Group 1994, 2007; Jones, 2010). Examples of these dimensions involved students' awareness of the House system, perceptions about transition from college/school, learning and teaching, opportunities for employability enhancement, academic and personal support, best practices and limitations of the system. The questions on awareness of the House system were preceded by a series of demographic questions that would allow the population to be segmented. The invitation email highlighted the voluntary participation in the survey, as well as the anonymity and confidentiality of the respondents. Prospective respondents were informed about the study's purpose in the invitation email, which explained that the results would be used in a project aiming at improving the student experience within the Programme. The survey results were recorded in Excel and transferred to SPSS for statistical analysis. The development, administration of the survey and data analysis took place from June to december 2014.

\section{Results and commentary}

Of the 775 students who received the invitation, 350 responded, representing a $45 \%$ response rate (Table 2).

When students were asked whether they were familiar with the House system, nearly half of the students (48\%) stated that they were familiar, with $41.33 \%$ being unfamiliar or highly unfamiliar (Figure 2).

High familiarity was not evident, indicating that although students may know the House system, they were not acquainted with what it actually does. In terms of whether their House had given them a sense of belonging during their studies, $44 \%$ disagreed with the statement, with $30.67 \%$ of them stating their agreement (Figure 3).

Considering that, nearly half of the respondents stated that they were familiar with the system, the fact that only $31 \%$ felt that their House gave them a sense of belonging, and $25.3 \%$ were undecided, early indicates concerns about the students' levels of familiarity and belongingness.

The most helpful aspects (list of the top-five aspects with the highest average mean value) were those associated with the Programme, such as academic skills development, active and challenging teaching and the contribution of the House tutors on issues that students raised (Table 3).

These aspects come in alignment with the Government's White Paper (Higher Education Funding Council for England [HEFCE], 2003) and with the recent Higher Education Policy Institute (HEPI) findings (Buckley, Soilemetzidis, \& Hillman, 2015) that the most important aspect of the academic service is the teaching ability of staff and their subject expertise. The aspects that students found the least helpful (list of the fiveaspects with thelowest averagemeanvalue), wereassociated withextracurricularactivities, employability and networking.

With regard to students' perceptions of whether their House had contributed to them being happy at university, 36\% seemed undecided, incomparison to $32 \%$ whostated anagreement $13.33 \%$ agree and $18.67 \%$ tend to agree) (Figure 4 ). 


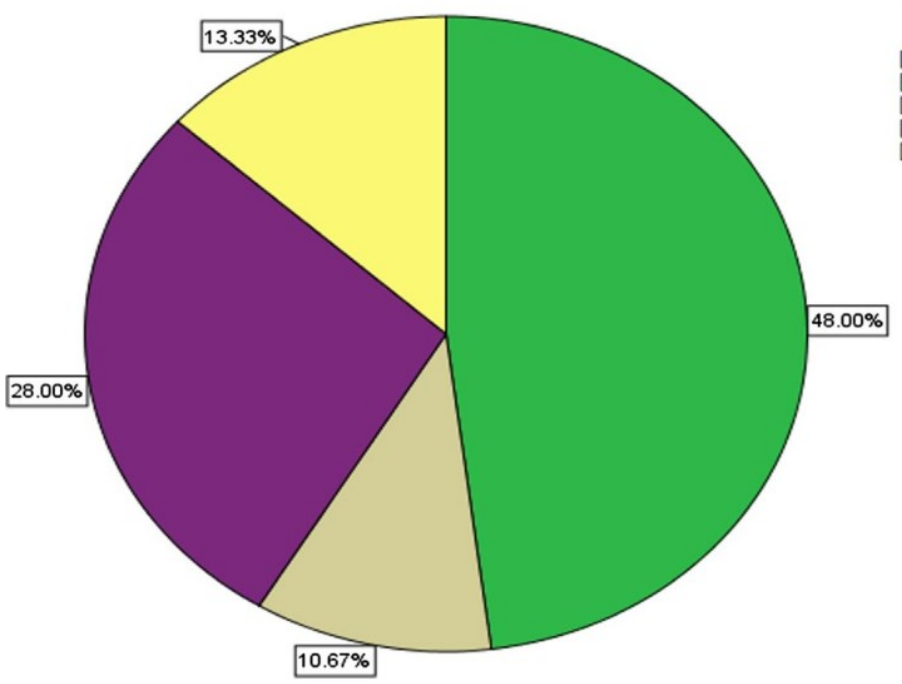

Are you familiar with what the House System is for?

Gighly familiar
$\square$ Familiar $\square$ Familiar Undecided Unfamiliar

Highly unfamiliar

Figure 2. students' familiarity with the house system.

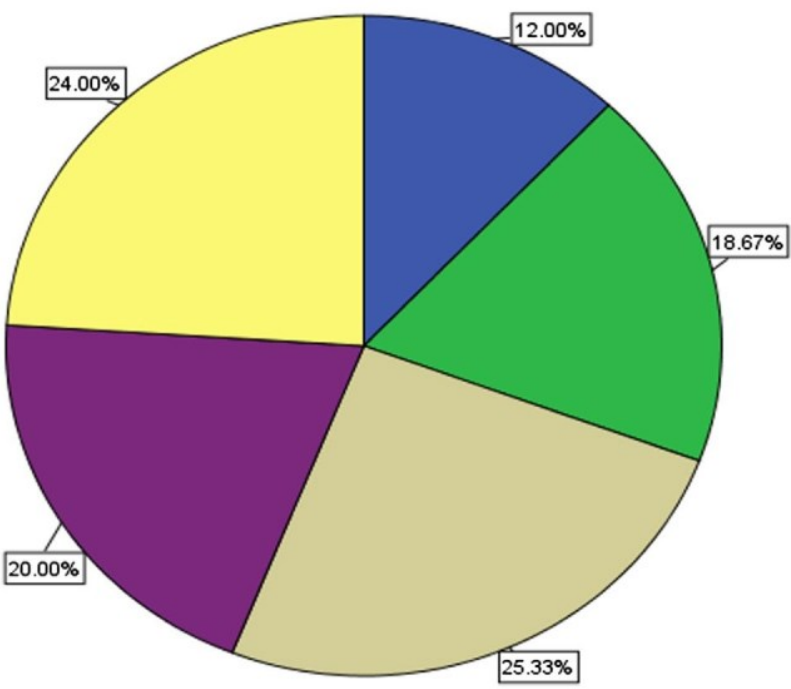

Would you agree that your House has given

you a 'sense of belonging' so far?

$\square$ Agree

Tend to agree

Neither agree or disagree

Tend to disagree

$\square$ Disagree

Figure 3. student's views on their house's'sense of belonging'.

Table 3. Most and least helpful aspects of the house system.

\begin{tabular}{lll}
\hline Ranking & Most helpful & least helpful \\
\hline 1 & academic skills development & Extracurricular activities \\
2 & active and challenging teaching & Employability/career development \\
3 & action taken by house tutor on issues that were raised & develop peer-networks \\
4 & Programme information advice & support on transition from school/college \\
5 & Induction & Meeting expectations as a student \\
\hline
\end{tabular}




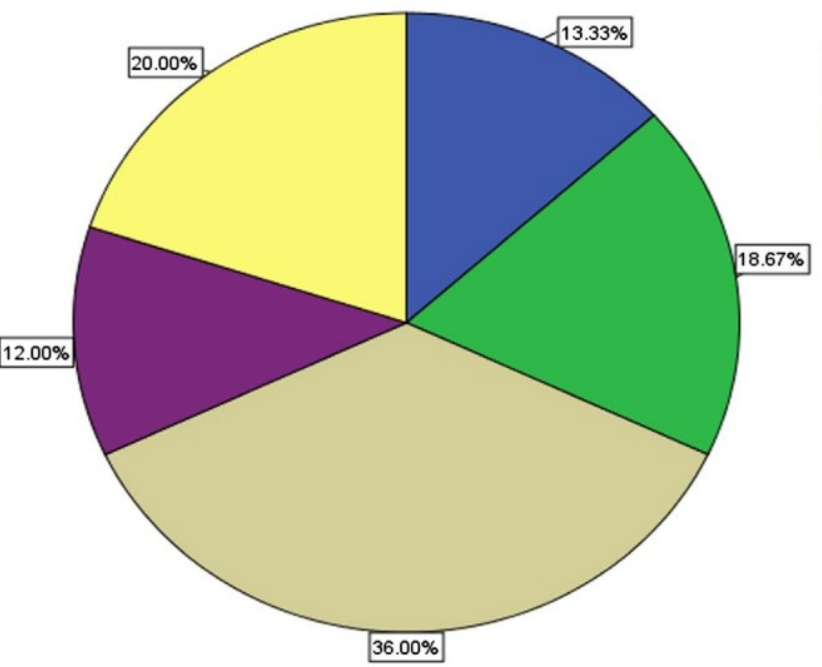

Do you agree that

your House has

helped you to be

happy at the

university?

$\square$ Agree
$\square$ Tend to agree

$\square$ Neither agree or disagree

Tend to disagree

$\square$ Disagree

Figure 4. students' views on their house's help in being happy at university.

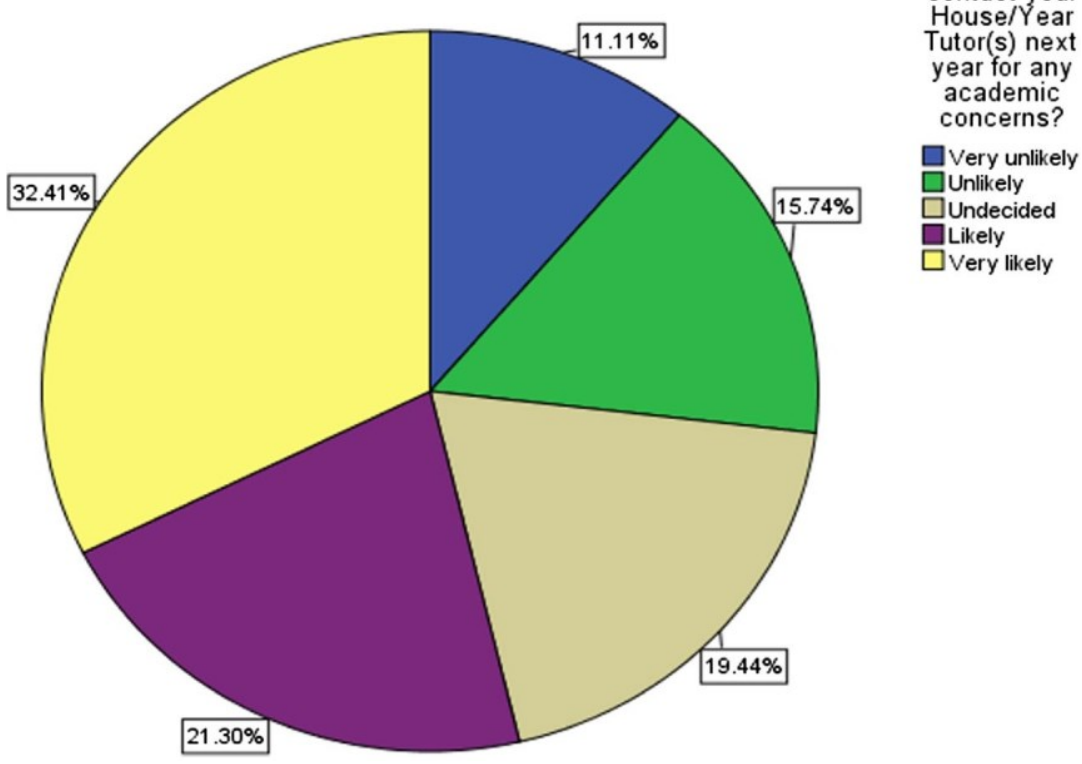

Figure 5. Iikeliness of contacting house tutors for personal concerns.

The students showed strong likeliness $(53.71 \%)$ to contact their House tutors for personal concerns and academic concerns (56\%) in the future, confirming research on the emphasis students give in having frequent meetings with their tutors as a factor that helps them be satisfied at university (Malik, 2000; Owen, 2002) (Figures 5 and 6). 

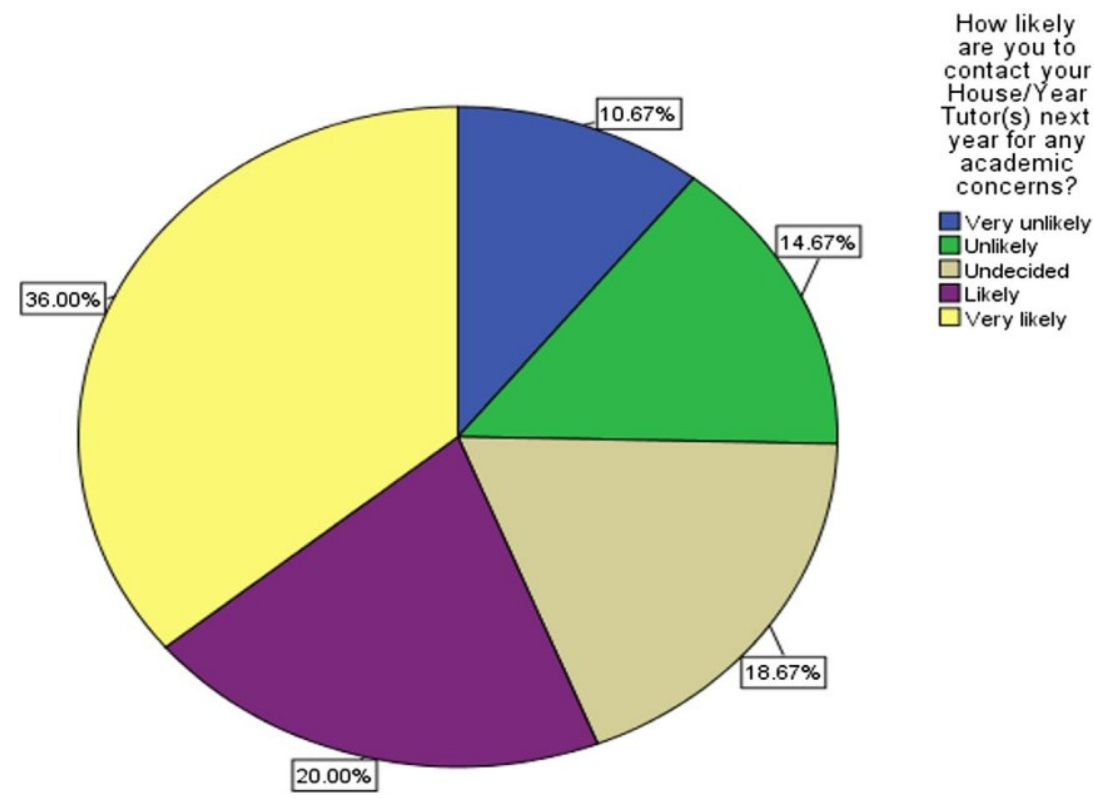

Figure 6. Iikeliness of contacting house tutors for academic concerns.

Table 4. Best and worst aspects of the house system.

\begin{tabular}{|c|c|c|}
\hline Ranking & Best & Worst \\
\hline 1 & Making friends with other Business students & networking \\
\hline 2 & $\begin{array}{l}\text { supporton personal/academic issues from my } \\
\text { house tutor(s) }\end{array}$ & out-of-class events \\
\hline 3 & Induction & opportunities for employability enhancement \\
\hline 4 & opportunities for skill boosting sessions & Feeling that I had someone to contact for advice \\
\hline 5 & $\begin{array}{l}\text { Expectations, problems and concerns were man- } \\
\text { aged appropriately }\end{array}$ & $\begin{array}{l}\text { Expectations, problems and conflict were appropri- } \\
\text { ately managed }\end{array}$ \\
\hline
\end{tabular}

This also comes in alignment with the HigherEducation Quality Council forEngland (HigherEducation Quality Council [HEQC], 1996) that stressed the importance of a strong student support system.

The best things about the House system were those associated with making friends, the support they receive from their House tutors on personal and academic issues, and induction (Table 4).

Students confirmed that establishing friendships and the quality of relationships with their tutors are two of the most important aspects that students value as central for their overall experience (Thomas, 2002; Wilcox, Winn, \& Fyvie-Gauld, 2005). The aspects that the students rated as being the worst were again the out-of-class events, networking and opportunities for employability.

A further analysis was undertaken to identify different segments of the respondent population. With regard to the students'views studying at different levels, the first-year students appeared slightly more familiar with the House system, and more likely to agree that their House had given them a sense of belonging (compared to mean between the levels of studies). Whilst acknowledging that the majority of the respondents were first-year students, results revealed differences in the things students found as helpful. Although first-year students ranked 'active and challenging teaching' as the most helpful aspect, it dropped to sixth in the helpfulness rankings of second-year students (Table 5).

Moreover, 'academic advice and support', was ranked second by first-year students, but it was the seventh mosthelpfulaspect for second-yearstudents. Clearly, thehelpfulness of the tutors on academic matters was evaluated differently, confirming that first-yearstudents rely more on the quality of teaching for their personal success and that an academic advisor who interacts with them and tells them 
Table 5. Most helpful aspects for First and second Year.

\begin{tabular}{lll}
\hline Ranking & Year 1 & Year 2 \\
\hline 1 & active and challenging teaching & academic skills development \\
2 & academic advice and support & action taken by house tutor \\
3 & academic skills development & Programme information advice \\
4 & action taken by house tutor & Employability/career development \\
5 & Programme information advice & Induction \\
6 & Induction & active and challenging teaching \\
7 & support on transition from school/college & academic advice and support \\
8 & develop peer-networks & Extracurricular activities \\
9 & Employability and career development & develop peer-networks \\
10 & Extracurricular activities & support on transition from school/college \\
\hline
\end{tabular}

Table 6. Best aspects for First and second Year students.

\begin{tabular}{|c|c|c|}
\hline Ranking & Year 1 & Year 2 \\
\hline 1 & Making friends with other Business students & Making friends with other Business students \\
\hline 2 & $\begin{array}{l}\text { supporton personal and academic issues from house } \\
\text { tutor(s) }\end{array}$ & $\begin{array}{l}\text { support on personal/academic issues from house } \\
\text { tutor(s) }\end{array}$ \\
\hline 3 & Induction & opportunities for skill-boosting sessions \\
\hline 4 & opportunities forskill-boosting sessions & Induction \\
\hline 5 & $\begin{array}{l}\text { Expectations, problems and concerns were managed } \\
\text { appropriately }\end{array}$ & opportunities for employability enhancement \\
\hline 6 & security feeling ofhaving someonetocontactforadvice & networking \\
\hline 7 & opportunities for employability enhancement & $\begin{array}{l}\text { Expectations, problems and concerns were managed } \\
\text { appropriately }\end{array}$ \\
\hline 8 & active and collaborative learning & security feeling of having someone to contact for advice \\
\hline 9 & networking & active and collaborative learning \\
\hline 10 & out-of-class events & out-of-class events \\
\hline
\end{tabular}

exactlywhat todo ismore important (Chickering \& Reisser, 1993). Anotherinconsistency occurred in the 'employability and career development'aspect, which was ranked as the fourth most helpful aspect for second-yearstudents, butwasranked as theninthmosthelpfulareaforfirst-years. Thiscould perhaps be explained by the fact that second-year students seek for employability support more rigorously as they are closer to a placement year or to employment. Contrary, academic-skills development, the actions taken by House tutors, and programmeadvice appeared as being helpful in both years. Again, areas of concern appeared the extracurricular activities and peer-networks development, as these were low ranked as being helpful. In terms of the best and worst things of the House system, bothyears agreed on almost all categories (Table 6).

With regards to mode of study, analysis did not show significant differences in the levels of awareness and perceptions. The rankings of the most helpful aspects showed that although the full-time students ranked 'Induction' as the fourth most helpful aspect, it was ranked seventh for the Placement students, indicating that Placement students, whose academic life lasts longer, have more expectations from orientation on campus life. In consistent with the overall population, Placement students also stated that developing friendships is the best thing of the House system, and poor networking the worst.

differences were not found between students' genders. The data were next segmented based on student nationality. Whilst recognising that the majority of the respondents were UK students, the levels of familiarity and rankingswereanalogous to therankings for EU and international students.

\section{Phase 2}

From the survey, a number of inconsistencies were identified, which required further clarifications. In particular, first-year students ranked 'active and challenging teaching' as the mosthelpful aspect of the system, whilst second-years ranked it sixth. Moreover, second-years considered 'employability and career development'asmorehelpful than first-years, although it was pointed byboth levels thatemployability 
opportunities were poor. The inconsistent responses on the areas of teaching and employability gave cause for qualitative research to clarify the students' perspectives.

Four focus group interviews, two from each year informed the study. Emails were sent to all business students, inviting them to attend a voluntary discussion about their perceptions of the House system. Ultimately, 24 students agreed to attend the interviews, 10 from first year and 14 from second year. Each group from first year comprised of five students, and each group from second year comprised of seven students. Unstructured open-ended questions were used providing with an opportunity to follow up the comments of and to hear issues from individuals with similar experiences in an interactive manner, which could not emerge from the questionnaire (liamputtong, 2011). Participants were given the option to withdraw and the results were made available for their further scrutiny to ensure the meanings of the discussions were commonly understood. A qualitative descriptive analysis was used to find common themes that appeared within the focus groups (Goodyear, Barela, Jewiss, \& Usinger, 2014).

\section{Results from focus groups}

Theinterviews focused on asking thestudents toexplain the role that their House had oneach of the student experience categories examined in the survey, to clarify inconsistencies and to provide recommendations of improvement. In terms of familiarity with the House system, students gave examples of experiences they had encountered about lack of awareness of which House they belong. A first-year student commented: 'I know who my House tutor is but it should be clearer as to what exactly is here for'. Similarly, a second-year student argued that 'we would like to understand why it's introduced and what it offers. It should be more like Hogwarts sense of belonging and making our house the best!'

There was consensus amongst participants about the decisive role of their House tutor in signposting, supporting and in facilitating transition. They also appreciated the degree of contact with them, commenting their enthusiastic and supportive nature. Most students thought that their House created a friendly environment, where it is easier to make friends and to feel that they have someone to rely on.

The interviews attempted to clarify the inconsistencies in relation to teaching. First-year students commented that they enjoyed their in-class experience, which allowed them to interact during stimulating activities, due to being mentored by enthusiastic staff. However, second-years referred to particular academics whose quality of teaching was not perceived as engaging. They agreed that lectures without the opportunity for interaction were disliked, something that did not occur in their first year. One second-year student said that'I now appreciate how helpful my tutors were last year. It's ridiculous to have a second lecture in my tutorials. It's a complete waste of my time'. The specific student argued that he had to turn to his House tutor and request to be removed to another tutorial group for a particular unit, with a more enthusiastic-perceived tutor. Other second-year students shared the perception that their Housetutors' intervention in ensuring they receivechallenging teachingwassignificant in theirstudies.

In responding to the recommendations they would suggest to improve the House system, all students referred to the improvement of employability and of extra-curricular activities that would help them develop their academic and personal skills. Particularly, asecond-yearstudent commented 'more house vs house activities would give more opportunities to network'.

\section{Taking the house system forward}

The study successfully fulfilled its objectives, namely to explore students'familiarity of the House system and perceptions in relation to student experience factors. The results gave an exceptionally strong basis for further monitoring the progress of this initiative, which helps in generating improvements for the next student cohorts.

Whilst evaluations of the experiences were generally positive, findings showed inadequate levels of awareness and familiarity of the House system, indicating the urgent need to communicate its role. The aspects considered as the most helpful were related to the areas of skill development, House tutors' support, induction and programme information. The students' engagement with their House tutors in 
critical times was also evidenced by their willingness to contact them again for any concerns, showing the respondents were essentially happy with the support they received. These findings are encouraging considering that teaching and learning, relationships with staff and university support services are key factors that influence student satisfaction and retention (Buckley et al. , 2015; Thomas, 2002; Umbach \& Wawrzynski, 2005). In an increasingly consumerist educational culture, where universities prioritise customer care for students (Scott, 1999), the House system appears as an effective means of ensuring that students are well-guided and supported.

noteworthywas theconsistencyamongstall respondents to rank the creation of friendships with other students as the best thing about their House, confirming the importance of developing social livesat university and creating courserelationships inthestudentexperience (Allenetal., 1999; Menzies \& Baron, 2014; Titus, 2004; Willcoxson, Cotter, \& Joy, 2011).

The aspects of concern were those related to employability, extracurricular activities, and students' expectations about university life, which were rated as the least helpful in the House system. In line with predictions that employability is increasingly important for students in preparing for the world of work (Foskett et al., 2006), students'recommendations were solely around out-of-class events, in-House competitions, and more help from their tutors on employability development.

The antithetic views in the two years'responses on the quality of teaching has practical implications for making better use of sharing best practice and using people from strongly performing subject areas to support others. Focusing on the quality of the educational experience, as well as ensuring the possession of teaching qualifications amongst all lecturers - as per recent calls (Buckley et al., 2015), are priority action points that could improve the consistency of teaching in all levels and ensure the active engagement of students in the classroom.

\section{Conclusions}

This paper focused on the evaluation of a scheme aiming to enhance the student experience, based on the perceptions of students from business studies. nevertheless, the study recognises that further research comparing the experiences and perceptions of a broader sample of undergraduate students, who were not involved in the House system, and exploring the views of other stakeholders (e.g. senior management, House tutors), can provide a more holistic evaluation of the system.

This study's contribution lies to the evaluation of innovative strategies in large courses, aiming to create the conditions for improving the student experience and are rare in the educational literature. It is argued that such strategies can have the potential to influence the students' feelings of identity and belonging, which can later be reflected via the national Student Survey. Given that now Universities compete for students both nationally and internationally, the retention and satisfaction of the students appears more urgent than ever. This can be achieved if all the aspects included in the student experience are delivered to a suitable standard. The students, as the sole judges of whether this has been achieved, should beencouraged to participate in feedback surveys on a regular basis to allow Universities to adapt accordingly.

\section{Disclosure statement}

no potential conflict of interest was reported by the author.

\section{Notes on contributor}

Marilena Antoniadou is a senior lecturer in Management, at Manchester Metropolitan University (MMU) Faculty of Business and Law. She studied her MA, MRes and Phd in Organisational Behaviour at MMU and specialises in the role of discrete emotions andemotional events in the workplace and particularly in the context of academia. Her research interests arealso within the field of Higher Education. She is a Fellow of Higher Education Academy and an Academic Member of the CIPd. 


\section{References}

Allen, T. d., McManus, S. E., \& Russell, J. E. A. (1999). newcomer socialization and stress: Formal peer relationships as a source of support. Journal of Vocational Behavior, 54, 453-470.

Benckendorff, P., Ruhanen, L., \& Scott, n. (2009). deconstructing the student experience: A conceptual framework. Journal of Hospitality and Tourism Management, 16, 84-93.

Buckley, A., Soilemetzidis, l., \& Hillman, n. (2015). Student survey puts teaching high on agenda. The HEPI-HEA student academic experience survey. York. Retrieved from http://www.hepi.ac.uk/2015/06/04/2015-academic-experience-survey/

Buultjens, M., \& Robinson, P. (2011). Enhancing aspects of the higher education student experience. Journal of Higher Education Policy and Management, 33, 337-346.

Byrne, M. , \& Willis, P. (2005). Irish secondary students' perceptions of the work of an accountant and the accounting profession. Accounting Education, 14, 367-381.

Chickering, A. W., \& Reisser, L. (1993). Education and identity (2nd ed.). San Francisco, CA: Jossey-Bass.

Christie, H., Tett, L., Cree, v. E., Hounsell, J., \& McCune, v. (2008). A real rollercoaster of confidence and emotions: learning to be a university student. Studies in Higher Education, 33, 567-581.

Cohen, L., Manion, L., \& Morrison, K. (2007). Research methods in Education. Iondon: Routledge.

Constanti, P., \& Gibbs, P. (2004). Higher education teachers and emotional labour. International Journal of Educational Management, 18, 243-249.

Foskett, n., Roberts, d., \& Maringe, F. (2006). Changing fee regimes and their impact on student attitudes to higher education. Southampton: University of Southampton.

Goodyear, L., Barela, E., Jewiss, J., \& Usinger, J. (2014). Qualitative inquiry in evaluation: From theory to practice. San Francisco, CA: JohnWiley.

Group 1994. (2007). Enhancing the student experience - Policy statement. london: author

Higher Education Funding Council for England. (2003). Final report of the teaching qualityenhancement committee on the future needs andsupport for quality enhancement of learning and teaching in higher education. Retrieved from http: / / www.hefce.ac.uk/learning/tqec/final.htm

Higher Education Quality Council. (1996). Personal tutoring and academic advice in focus. london: author.

Hockings, C., Cooke, S., \& Bowl, M. (2007). Academic engagement within a widening participation context - a 3d analysis. Teaching in Higher Education, 12, 721-733.

Jones, R. (2010, december). So just what is the student experience? The development of a conceptual framework for the student experience of undergraduate business students based on the themes emerging in the academic literature. Paper delivered at the SRHE Annual Research Conference, newport.

Kantanis, T. (2000). The role of social transition in students' adjustment to the first-year of university. Journal of Institutional Research, 9, 100-110.

King, M., Morison, I., Reed, G., \& Stachow, G. (1999). Student feedback systems in the business school: A departmental model. Quality Assurance in Education, 7, 90-100.

Kuh, G. d. (1995). The other curriculum: Out-of-class experiences associated with student learning and personal development. The Journal of Higher Education, 66, 123-155.

liamputtong, P. (2011). Focus group methodology: Principles and practice. Iondon: Sage.

Malik, S. (2000). Students, tutors and relationships: The ingredients of a successful student support scheme. Medical Education, 34, 635-641.

Menzies, J. L., \& Baron, R. (2014). International postgraduate student transition experiences: The importance of student societies and friends. Innovations in Education and Teaching International, 51, 84-94.

Oldfield, B. M. , \& Baron, S. (2000). Student perceptions of service quality in a UK university business and management faculty. Quality Assurance in Education, 8, 85-95.

Owen, M. (2002). 'Sometimes you feel you're in niche time': The personal tutor system, a case study. Active Learning in Higher Education, 3, 7-23.

Palmer, M. , O’Kane, P., \& Owens, M. (2009). Betwixt spaces: Student accounts of turning point experiences in the first-year transition. Studies in Higher Education, 34, 37-54.

Peat, M., dalziel, J., \& Grant, A. (2001). Enhancing the first year student experience by facilitating the development of peer networks through a one-day workshop. Higher Education Research \& Development, 20, 199-215.

Ramsden, P. (2008). The future of higher education : Teaching and the student experience. The Higher Education Academy. Retrieved from http: //www.heacademy.ac.uk/re

Ritzer, G. (1999). The McDonaldization thesis: Explorations and extensions. london: Sage.

Rothwell, A. , Herbert, I. , \& Rothwell, F. (2008). Self-perceived employability: Construction and initial validation of a scale for university students. Journal of Vocational Behavior, 73, 1-12.

Scott, S. v. (1999). The academic as service provider: Is the customer always' right? Journal of Higher Education Policy and Management, 21, 193-202.

Terenzini, P., Pascarella, E., \& Blimling, G. (1996). Students' out-of-class experiences and their influence on learning and cognitive development: A literature review. Journal of College Student Development, 37, 149-162. 
Thomas, l. (2002). Student retention in higher education: The role of institutional habitus. Journal of Education Policy, 17, 423-442.

Titus, M. A. (2004). An examination of the influence of institutional context on student persistence at 4-year colleges and universities: A multilevel approach. Research in Higher Education, 45, 673-699.

Umbach, P. d., \& Wawrzynski, M. R. (2005). Faculty do matter: The role of college faculty in student learning and engagement. Research in Higher Education, 46, 153-184.

Wilcox, P., Winn, S., \& Fyvie-Gauld, M. (2005). It was nothing to do with the university, it was just the people: The role of social support in the first-year experience of higher education. Studies in Higher Education, 30, 707-722.

Willcoxson, L., Cotter, J., \& Joy, S. (2011). Beyond the first-year experience: The impact on attrition of student experiences throughout undergraduate degreestudies in six diverseuniversities. StudiesinHigherEducation, 36, 331-352. 